Yuriy Petrushenko,

Dr.Sc., Professor, Sumy State University, Ukraine

Viktor Ventsel,

Ph.D., National Academy of Public Administration under the President of Ukraine, Ukraine

Veronica Garbuz,

Ph.D., Alecu Russo Balti State University, Republic of Moldova

Uliana Kolomilets,

Charles University, the Economics Institute of the Czech Academy of Sciences, Czech Republic

Wojciech Duranowski,

Ph.D., University of Opole, Poland

\title{
INNOVATIONS IN MANAGEMENT OF FISCAL EQUALISATION: DECENTRALISATION REFORM
}

Abstract. The article summarises the results of scientific analysis of the effectiveness of the system of horizontal financial equalisation as a tool for reducing inter-territorial economic and social disparities. The primary purpose of this study is to substantiate innovative approaches to improving the efficiency of the system of financial equalisation and operational management of financial imbalances of territories in the context of decentralisation reform. The subject of the study is the processes of management of the financial equalisation system in Ukraine since 2015, as it was at this time that the decentralisation reform began, the basis of which was the redistribution of financial resources. The presence of several unresolved practical and, therefore, technical and methodological tasks in the process of implementing the financial equalisation policy in Ukraine in the period 2015-2020 has made the research relevant. The comparative analysis of the system of horizontal financial equalisation in Ukraine in terms of its effectiveness in reducing inter-territorial fiscal imbalances and assessing the effectiveness of the authors' innovative approaches to managing the financial equalisation system became a methodological tool of the study. Statistical and econometric methods were used to verify the obtained results. The results of the study showed that the current approach to financial equalisation of disparities in the local budgets of Ukraine is not sufficient and needs improvement. New management approaches have been developed in the system of financial management of territories aimed at improving the mechanism of horizontal equalisation of local budgets, in particular, at reducing the number of local budgets, which receive essential subsidies from the state budget and improving the efficiency of the horizontal equalisation system in terms of reducing financial disparities between local budgets. Because of these goals, the analysis of the inclusion of the country's capital (Kyiv) into the national financial equalisation system was carried out. The study also substantiates the need for permanent monitoring of financial equalisation effectiveness. For a better understanding of how effectively the system of horizontal equalisation of fiscal revenues of territories functions, it is proposed to carry out a constant (annual) analysis of standard deviation indicators and other indicators that characterise its effectiveness. The results of the study can be useful both for state bodies planning and implementing the state budget and for implementing local financial policies by local self-governments.

Keywords: management, innovation, financial equalisation, budget, imbalance, asymmetry, decentralisation.

Introduction. The objective phenomenon is different levels of development of territories and different levels of their financial viability considering the uneven distribution of productive forces, natural resources, geographical, historical, cultural and other factors. At the same time, the state should provide an adequate standard of living for its citizens, regardless of their place of residence. One of the ways to reduce interterritorial economic and social disparities is to balance the financial (budgetary) viability of regions through the redistribution of budgetary resources. Through financial equalisation, the state is able to ensure the implementation of economic and social policies related to the provision of public services of appropriate standardised quality and quantity to its citizens on any territory, regardless of the financial viability of local self-governments. The financial mechanism of decentralisation reform, implemented in Ukraine since 2015 to improve the quality of life of the population, was based on financial equalisation instruments: necessary

Cite as: Petrushenko, Y., Ventsel, V., Garbuz, V., Kolomiiets, U., \& Duranowski, W. (2020). Innovations in Management of Fiscal Equalisation: Decentralization Reform. Marketing and Management of Innovations, 1, 208-221. http://doi.org/10.21272/mmi.2020.1-17 

Decentralization Reform

and reverse subsidies to newly created territorial communities. However, the implemented system of financial (budgetary) equalisation does not fully achieve the goal of reducing financial disparities and providing citizens with a guaranteed package of public services. In some cases, these imbalances are compounded by the reform. It justifies the need for further research and development of new approaches to improving the system of financial (budgetary) equalisation in the context of the creation of integrated territorial communities in the process of decentralisation reform.

Literature Review. The problem of financial equalisation of social and economic imbalances of territories is urgent all over the world and is studied all the time. The development of social relations, the transformation of economic and political spheres, as well as the need for balanced development of countries require a permanent search for new methods of eliminating financial asymmetry between regions and new instruments of state influence on these processes. Today, there is little research on various aspects of financial equalisation, but given the specific nature of this issue for each region, it does not lose its relevance.

G. Anetsberger and V. Arnold (2019) analysed the model according to which the central government could establish a system of vertical equalisation, while regional authorities could apply a system of horizontal equalisation. The central and local authorities make decisions regarding equalisation not simultaneously but in different chronological order. The study found that, regardless of the timing of the decision-making process, the central government always prevails and horizontal equalisation does not occur. However, the equilibrium is Pareto-effective only if the central government plays the role of a leader in this process (Stackelberg leader). Moreover, if the goal of achieving equal living conditions in the regions is pursued, then the only optimal option to achieve this goal is vertical equalisation.

The monograph «Intergovernmental Transfers in Federations» (2020) presents some generalised conclusions about the international experience in solving the most fundamental problems in the field of horizontal and vertical imbalances through the prism of intergovernmental transfers. The authors of the monograph study various aspects of policymaking aimed at improving the efficiency of inter-budgetary transfers as a tool to achieve the structure and volumes of expenditures, which contributes to the improvement of the quality of public services to the population. The book demonstrates that, as with many other political issues, the best decisions regarding the system and volumes of inter-budgetary transfers are almost always specific and very rarely generalised; that is, the decisions for a particular country must be made based on the specific situation in that country. In order to understand the system of interbudgetary transfers of any country, it is necessary to understand the complex and often changing conditions and institutions that form the taxation system, types and volumes of expenditures and interbudgetary fiscal relations in general. Given that each country has its history, political and economic conditions, each transfer system is specific. Reforms of the transfer policy always require, on the one hand, an understanding of significant technical complexities required to create an effective transfer system and, on the other hand, sensitivity and understanding of realities of the relevant political, institutional and economic context. One can rarely find a universal way of inter-budgetary relationships. Some significant problems such as vertical and horizontal imbalances, regional differences in resources and infrastructure, inequity in the provision of essential social services, to some extent, exist in each country. However, the methods and ways of transferring resources are usually dependent on specific local peculiarities. Therefore, it is difficult to define a universal system that takes into account all the specificities of all countries. That is why the reforms of transfer relationships will continue to be developed based on the relevant local context rather than based on some good examples or best practices of others.

Y. Carreras (2016) addresses the issue of whether the existence of regions with broader taxing powers is related to higher levels of economic inequality in the country. Literary sources long ago established a definite link between decentralised management and different levels of resource redistribution in the country. Redistribution is a tool by which governments tackle inequality, and if redistribution is asymmetric 

Decentralization Reform

between regions, it exacerbates inequality. Usually, decentralised governance, redistribution and economic inequality are always related in research works.

The study focuses on the economic dimension of decentralisation and presents a theory for understanding why the levels of government decentralisation are essential for income inequality. Using a particular set of data and measurements in the area of fiscal autonomy and fiscal control, the author explains why fiscal decentralisation increases inequality and at the same time suggests that joint distribution of fiscal powers between regions and the centre can reduce inequality.

J. Becker and M. Kriebel (2017) considered the issue of optimal tax equalisation on the territory of federal land that competes with another federal land. In certain circumstances, the federation is interested in stimulating tax competition to attract tax bases from other federal lands. The authors note that optimal fiscal equalisation helps to redistribute income from fertile regions to the poor ones and to choose the optimal level of tax competition. The optimal level of tax competition is a compromise between three goals. Firstly, decentralised tax rates have positive fiscal external phenomena within the federation in terms of attracting investment. In this case, tax rates are ineffectively low. Secondly, ineffectively high rates are the reason for deterring investments. Thirdly, the generous fiscal equalisation within the federation makes it possible to carry out a policy of non-aggressive competition with other federations for tax bases. Consequently, with optimal equalisation equilibrium tax rates are higher within and outside the federation, and even higher than in the case of centralised (that is, the federal level) tax rates.

The problem of financial equalisation of interregional disparities is urgent for all regions of the world. Quite often, it is considered in combination with the decentralisation of power, which has been the dominant tendency in the development of social and political relations over the last 30-40 years. China's asymmetric fiscal decentralisation system has often been criticised. At the same time, few studies have been conducted that directly testify to its negative impact on spending policies of local governments. Y. Li conducted a study on the asymmetric decentralisation system in China (Li, 2018) in terms of the stimulating impact of asymmetric decentralisation and fiscal transfers on spending policies of local governments.

The study used provincial panel data to perform an empirical test. Y. Li concluded that asymmetric decentralisation significantly weakens the incentives for local governments to increase social spending, whereas fiscal transfers do not play a proper role in solving asymmetric decentralisation (Li, 2018). Due to the relatively high impact of revenues the mechanism of financing of fiscal transfers not only significantly reduces the incentives of local governments to provide social public goods, but also weakens the restrictive effect of fiscal competition in spending policies of local governments by increasing their relative value. Although the mechanism of distribution of fiscal transfers has a significant positive incentive for local governments in regions where the net income of fiscal resources exceeds zero, the overall effects of fiscal transfers on the distribution of local government incentives to provide public goods are harmful in all regions ( $\mathrm{Li}, 2018$ ). Therefore, the view is confirmed that fiscal equalisation mechanisms have a diversified impact on the development of regions, and it is impossible to ensure an absolute equalisation of financial imbalances.

T. Vasileva and S. Lyeonov (2012) attempted to investigate the impact of financial imbalances of territories on opportunities to attract investments. M. Palienko et al. (2017) identified the role of fiscal decentralisation and its impact on macroeconomic stability. L. Kozarezenko et al. (2018) analysed the impact of fiscal decentralisation in Ukraine on the development of human capital in territorial communities. T. Vasylieva et al. (2018) analysed the arguments and counterarguments within the scientific debate on determining the optimal level of decentralisation that would contribute to the country's innovative development. O. Chygryn et al. (2018) developed an approach to assessing the impact of fiscal decentralisation on socio-economic development indicators.

Tiutiunyk (2018) analysed the impact of various financial instruments on the sustainable development of the region. A. Subeh Musa and V. Boychenko (2018) analysed the peculiarities of the financial crisis in 

Decentralization Reform

the implementation of innovative financial management tools. Bilan et al. (2019) examined the impact of financial inequality on business development and building of public trust.

S. Kandula (2017) devoted his study to the mechanism of equalisation of municipal budgets used in Poland. The author considers the hypothesis that the mechanism of budget equalisation for municipalities used in Poland consists of three parts of the total subsidy. It is noted that such mechanism reduces the differences between municipalities in terms of per capita income, but the effectiveness of specific transfers is changing. Income differences between municipalities were examined by using the ratio of minimum and maximum values to the average indicator and variation coefficient. It is determined that the most effective transfer is the equalisation part of the total subsidy. The tools of horizontal equalisation have limited impact on the reduction of disparities between municipalities. These discrepancies can be smoothed out by the redistribution of transfers (Kandula, 2017).

It is believed that unlike vertical fiscal imbalances, the system of horizontal fiscal imbalances and inequalities between local self-governments was not sufficiently studied due to different fiscal capacities. Italian researchers (Di Liddo et al., 2016) proposed a new method of calculating fiscal capacity based on regression analysis, which can overcome some of the disadvantages of traditional methods, such as a representative (typical) taxation system.

By using the example of Canada D. Albouy (2012) notes that federal transfers should ignore differences in regional expenditures and offset differences in federal tax payments and local taxes. Transfers, which are fairly distributed among regions, are likely to be directed to low-income regions. The author notes that the Canadian equalisation policy is not sufficient and fair. Economic inefficiencies cost Canada $0,41 \%$ of revenues annually leading to overfunded provinces having populations that are $30 \%$ higher than their sufficient long-term levels (Albouy, 2012).

At the same time, despite numerous studies of the system of inter-budgetary relations and budgetary equalisation, this topic remains relevant because of the continual development of social relations, improvements and changes in social and budgetary policies for the justification and effective implementation of administrative and territorial reforms.

The article aims to evaluate the effectiveness of the system of financial equalisation in Ukraine and to substantiate innovative management approaches and their improvement in the context of decentralisation reforms.

Methodology and research methods. In carrying out the study, such general scientific and specific methods as abstraction, formalisation, axiomatic method, methods of retrospective and statistical analysis were used. In particular, the study is based on the analysis of financial indicators that characterise the system of financial equalisation of local budgets. The data on the implementation of local budgets of Ukraine in the period 2017-2020 and the indicators of statistical reporting regarding the number of population in territorial communities were used. The analysis of the financial equalisation system used in the past was performed Using the retrospective method. The comparative analysis was used to compare the results of the application of several alternative innovation scenarios in investigating the system of financial equalisation of local budgets. The hypothesis about the effectiveness of the system of horizontal equalisation in terms of reducing financial imbalances between local budgets when applying multiple scenarios and approaches to the calculation of transfers was tested by using the empirical research method. When making calculations and formulating conclusions, the methods of mathematical statistics were used to systematise and process the financial indicators that characterise the system of financial equalisation of local budgets. The study also used the Delphi technique to model different innovation options for managing the financial equalisation system of local budgets and making conclusions based on practical experience, expert judgments and assumptions.

Results. The system of budgetary equalisation in Ukraine has undergone periodic changes and transformations throughout the years of independence in order to form the most optimal approaches to 

Decentralization Reform

reduce the existing inter-territorial disparities in the provision of financial resources. The existing system of horizontal equalisation of local budgets was introduced in 2015 when several legislative and regulatory acts aimed at reforming the local self-government and territorial organisation of authorities were adopted.

One of the significant innovations was the new mechanism of budgetary adjustment and equalisation, namely the transition from a three-tier to a two-tier budget model. Earlier, until 2015, the equalisation subsidy was provided from the state budget to regional budgets, budgets of cities of regional significance and district budgets. That is, there were direct inter-budgetary relations between these budgets and the state budget. Further, district budgets distributed equalisation subsidies in the amount determined by the law on the state budget to the budgets of villages, settlements and towns of district importance. Therefore, equalisation subsidies were divided into three levels: regional budget; budgets of towns of regional importance and district budgets; budgets of villages, settlements and towns of district importance.

Budgetary legislation provides for the establishment of direct inter-budgetary relations at only two levels - regional budget and the second level - cities of regional significance, amalgamated community and district budgets starting from 2015. The law states that amalgamated community are vested with the same powers as cities of regional significance and regional budgets, and those communities, which are not united, are accordingly deprived of the power to exercise the authority delegated by the state, as well as the appropriate revenue sources for their budgets.

The Budget Code of Ukraine introduced such concepts as base subsidy and reverse subsidy. The base subsidy is defined by Article 96 of the Budget Code as a transfer provided from the state budget to local budgets for horizontal equalisation of the tax capacity of territories. Reverse subsidies are funds transferred to the state budget from local budgets for horizontal equalisation of the tax capacity of territories (Biudzhetnyi kodeks Ukrainy).

Therefore, the amendments to Budget Code in 2015 were replaced by a system of budgetary equalisation that provides for horizontal equalisation of the tax capacity of territories depending on the level of per capita income. In other words, local budgets were balanced earlier based on the necessity to spend money on the sectors of the budget sphere according to formulaic approach - calculation of expenditures provided by the state, determination of revenues and, in case of excess of expenditures over revenues, equalisation subsidy was granted. Otherwise, if the estimated amount of revenues exceeded the estimated amount of expenditures, these extra revenues were deducted from the relevant local budget to the state budget (Figure 1).

The new model of budgetary relations conducts equalisation not according to expenditures, but revenues. The primary purpose of providing a basic or reverse subsidy is to equalise the fiscal capacity of local budgets (Figure 2).

At the same time, equalisation is carried out only for two types of taxes:

- corporate income tax - for regional budgets;

- personal income tax - for cities of regional significance, budgets of the amalgamated community, district budgets and regional budgets.

Other payments to local budgets are not equalised, in other words, their amounts do not affect the amounts of base or reverse subsidies. According to the intention of lawmakers, such consolidation of revenue sources should contribute to increase in the revenue base of local budgets, since the state does not influence such revenues (in terms of considering them in carrying out budgetary equalisation). 


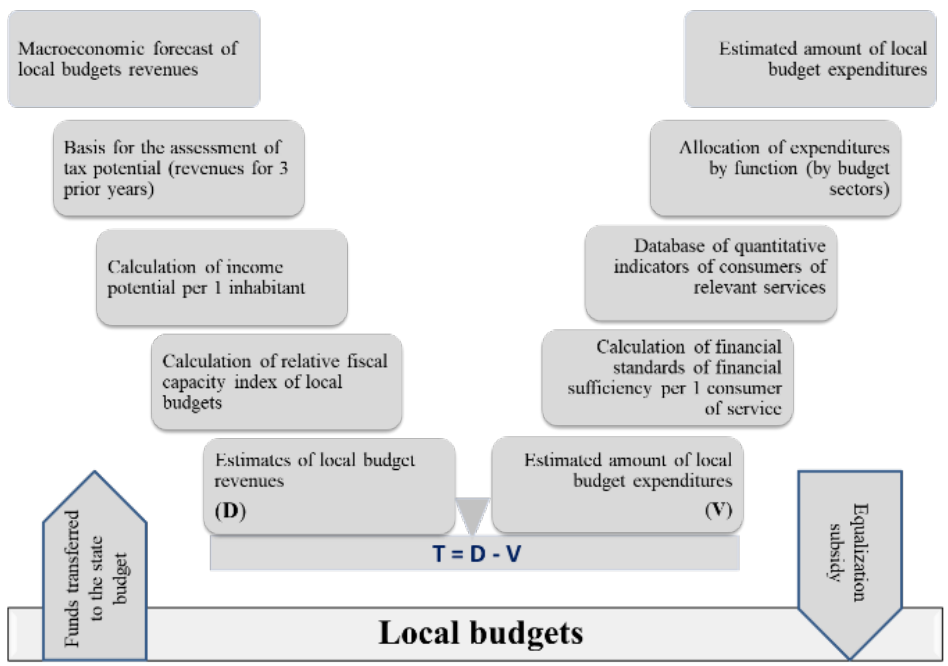

Figure 1. Formation of inter-budgetary transfers under conditions of vertical equalisation Source: developed by the authors.

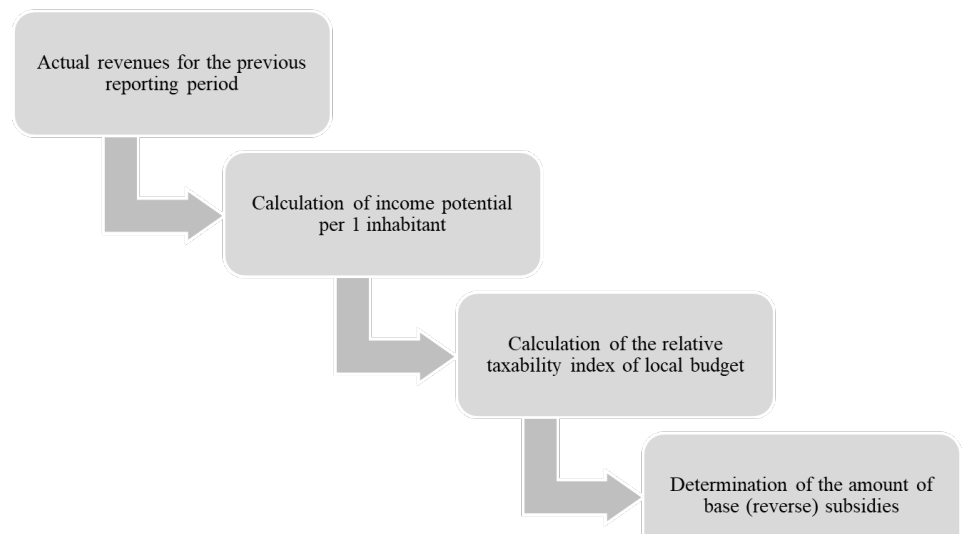

Figure 2. Formation of inter-budgetary transfers under conditions of horizontal equalisation Source: developed by the authors.

To calculate the base and reverse subsidies we use the number of residents, income tax from individuals over the reporting period and the index of taxability, which is a coefficient that determines the level of per capita taxability of the relevant local budget compared to the average of all consolidated local budgets in Ukraine. The mechanism of equalisation assumes that local budgets with a value of taxability below 0,9 of the average in Ukraine, receive a base subsidy ( 80 per cent of the amount needed to reach the value of 0,9 ). For local budgets with levels of revenues from 0,9 to 1,1 , no equalisation is made. Budgets with higher per capita income provide to the state budget a reverse subsidy of $50 \%$ from the value exceeding the taxability index of 1,1 to the average in Ukraine.

Let us consider some aspects of the horizontal equalisation system of Ukraine in terms of its effectiveness and ability to eliminate interregional financial imbalances. 
Y. Petrushenko, V. Ventsel, V. Garbuz, U. Kolomiiets, W. Duranowski. Innovations in Management of Fiscal Equalisation: Decentralization Reform

In the period 2017-2020, the amount of necessary subsidy from the state budget to local budgets increased by 2,3 times (or by 7,5 billion UAH) - from 5,8 billion UAH to 13,3 billion UAH (Table 1, Figure 1). The volume of reverse subsidies transferred by local budgets to the state budget increased by 2,2 times (or by 4,8 billion UAH) - from 3,9 billion UAH to 8,8 billion UAH (Table 1, Figure. 3 ).

Table 1. Volumes of necessary and reverse subsidies in 2017-2020 by local budgets, mln. UAH

\begin{tabular}{|c|c|c|c|c|c|c|}
\hline \multirow{2}{*}{ Year } & $\begin{array}{c}\text { Type of } \\
\text { subsidy }\end{array}$ & $\begin{array}{c}\text { Regional } \\
\text { budgets }\end{array}$ & $\begin{array}{c}\text { District } \\
\text { budgets }\end{array}$ & $\begin{array}{c}\text { Budgets of cities of } \\
\text { regional significance }\end{array}$ & $\begin{array}{c}\text { Budgets of } \\
\text { amalgamated } \\
\text { community }\end{array}$ & Total \\
\hline \multirow{2}{*}{2017} & Basic & 909,2 & 3746,5 & 391,7 & 768,1 & 5815,5 \\
\cline { 2 - 7 } & Reverse & 652,2 & 366,9 & 2745,9 & 157,9 & 3922,9 \\
\hline \multirow{2}{*}{2018} & Basic & 1039,5 & 4598,2 & 647,3 & 1897,6 & 8182,6 \\
\cline { 2 - 7 } & Reverse & 732,0 & 503,4 & 3668,0 & 503,1 & 5406,5 \\
\hline \multirow{2}{*}{2019} & Basic & 1380,4 & 5419,2 & 768,3 & 2799,5 & 10367,3 \\
\cline { 2 - 7 } & Reverse & 941,0 & 573,5 & 4271,9 & 1032,8 & 6819,1 \\
\hline \multirow{2}{*}{2020} & Basic & 2043,0 & 6563,6 & 876,9 & 3798,8 & 13282,4 \\
\cline { 2 - 7 } & Reverse & 1367,9 & 621,0 & 4886,1 & 1888,4 & 8763,4 \\
\hline
\end{tabular}

Source: developed by the authors (State budget of Ukraine in 2017-2020).

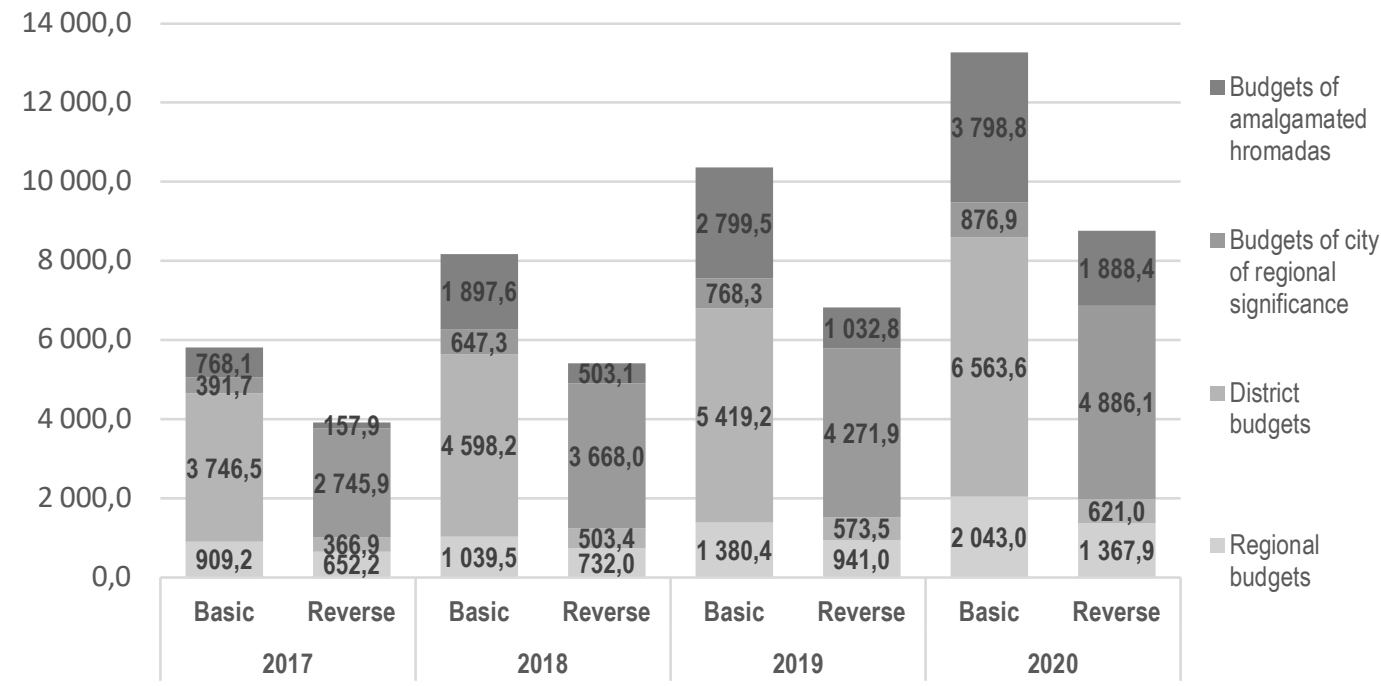

Figure 3. Dynamics of volumes of basic and reverse subsidies in 2017-2020, million UAH

Source: developed by the authors (State budget of Ukraine in 2017-2020).

In 2020 (as in previous years) of the total amount of the necessary subsidy, the most significant amount is allocated for district budgets $(49,4 \%)$ and the lowest - for the budgets of cities of regional significance $(6,6 \%)$. The situation is the opposite regarding reverse subsidy - the most substantial amount is transferred to the budgets of cities of regional significance $(55,8 \%)$, the smallest - to district budgets $(7,1 \%)$. 

Decentralization Reform

In the context of financial equalisation, the main question is how the existing system ensures the reduction of imbalances between local budgets. Because of this, the system of horizontal equalisation of local budgets in Ukraine was studied. The study focused on two aspects:

1. A search for opportunities to reduce the number of local budgets receiving essential subsidies from the state budget.

2. An increase inefficiency of the system of horizontal equalisation in reducing financial imbalances between local budgets.

Table 2. Volumes of necessary and reverse subsidies in 2020 by types (levels) of local budgets

\begin{tabular}{|c|c|c|c|c|c|c|c|c|}
\hline \multirow{2}{*}{$\begin{array}{c}\text { Budget } \\
\text { levels }\end{array}$} & $\begin{array}{c}\text { number } \\
\text { of } \\
\text { budgets }\end{array}$ & $\begin{array}{c}\text { the } \\
\text { amount, } \\
\text { million } \\
\text { UAH }\end{array}$ & $\begin{array}{c}\text { share in the } \\
\text { total amount } \\
\text { of subsidy }\end{array}$ & $\begin{array}{c}\text { the average } \\
\text { amount of } \\
\text { subsidy per } \\
\text { budget, } \\
\text { million UAH }\end{array}$ & $\begin{array}{c}\text { number } \\
\text { of } \\
\text { budgets }\end{array}$ & $\begin{array}{c}\text { Reverse subsidy } \\
\text { amount, } \\
\text { million } \\
\text { UAH }\end{array}$ & $\begin{array}{c}\text { share in } \\
\text { the total } \\
\text { amount } \\
\text { of } \\
\text { subsidy }\end{array}$ & $\begin{array}{c}\text { the average } \\
\text { amount of } \\
\text { subsidy per } \\
\text { budget, } \\
\text { million UAH }\end{array}$ \\
\hline A & 1 & 2 & $3=2 / \sum 2$ & $4=2 / 1$ & 5 & 6 & $7=6 / \Sigma$ & $6=6 / 5$ \\
\hline $\begin{array}{c}\text { Budgets of } \\
\text { amalgamated } \\
\text { community }\end{array}$ & 622 & 3798,8 & $28,6 \%$ & 6,1 & 146 & 1888,4 & $21,5 \%$ & 12,9 \\
\hline $\begin{array}{c}\text { Budgets of } \\
\text { cities of } \\
\text { regional } \\
\text { significance }\end{array}$ & 38 & 876,9 & $6,6 \%$ & 23,1 & 49 & 4886,1 & $55,8 \%$ & 99,7 \\
\hline $\begin{array}{c}\text { District } \\
\text { budgets }\end{array}$ & 358 & 6563,6 & $49,4 \%$ & 18,3 & 37 & 621,0 & $7,1 \%$ & 16,8 \\
\hline $\begin{array}{c}\text { Regional } \\
\text { budgets }\end{array}$ & 19 & 2043,0 & $15,4 \%$ & 107,5 & 5 & 1367,9 & $15,6 \%$ & 273,6 \\
\hline Total & 1037 & 13282,4 & $100,0 \%$ & 12,8 & 237 & 8763,4 & $100,0 \%$ & 37,0 \\
\hline
\end{tabular}

Source: developed by the authors (State budget of Ukraine in 2017-2020).

The study of the first aspect was based on the hypothesis that an extension of horizontal equalisation of the financial base would reduce the number of local budgets requiring base subsidies from the state budget. The study was conducted for district budgets, budgets of cities of regional significance and budgets of amalgamated community, for which the calculation of their taxability index is based on the income tax of individuals. Given that regional budgets apply different criteria and a different order of calculation than local budgets, their indicators were not used in the study. The simulation was based on the calculation base used in calculations for 2020.

Following the existing equalisation system, in 2020, the state budget of Ukraine provides essential subsidies for 1018 budgets (except for regional budgets) for 11,2 billion UAH (Table 2). The provision of reverse subsidies is planned for 232 budgets in the amount totalling 7,4 billion UAH (Table 2). Therefore, the volumes of essential subsidies exceed reverse subsidies by 3,8 billion UAH. This amount is intended for the financing of essential subsidies directly from the state budget, and not from reverse subsidies. Accordingly, it can be stated that Ukraine has no classic horizontal equalisation system, which is a selfbalanced system in which the volumes of essential subsidies are equal to the volumes of reverse subsidies.

Provided that the calculation base of the taxability index includes not only the personal income tax but also other types of national taxes (except for local taxes and fees for administrative services), we will obtain the following results shown in Table 3, namely: the number of reverse subsidies - 9,4 billion UAH; 

Decentralization Reform

the number of essential subsidies $-12,7$ billion UAH; the number of budgets receiving base subsidies 973. Provided that not only the personal income tax but also national payments are included in the horizontal equalisation system, the number of budgets receiving essential subsidies will be 973 , which is $4,4 \%$ or 45 budgets less than in the present conditions. At the same time, the number of funds to be drawn from the state budget to provide essential subsidies will decrease by $13,9 \%$. Therefore, we can conclude that with the expansion of the financial equalisation base, the share of subsidised local budgets and the amount of state budget funds involved in the equalisation system, are decreasing.

Table 3. Indicators of horizontal equalisation of local budgets

\begin{tabular}{|c|c|c|c|c|c|c|c|c|c|c|}
\hline \multirow{2}{*}{ № } & \multirow{2}{*}{$\begin{array}{c}\text { Criteria of } \\
\text { horizontal } \\
\text { equalisatio } \\
n\end{array}$} & \multirow{2}{*}{ 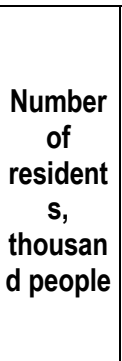 } & \multirow{2}{*}{$\begin{array}{c}\text { Revenue } \\
\text { s for } \\
2018, \\
\text { mln. } \\
\text { UAH }\end{array}$} & \multirow{2}{*}{$\begin{array}{c}\text { Per } \\
\text { capita } \\
\text { revenue }\end{array}$} & \multicolumn{2}{|c|}{$\begin{array}{l}\text { Reverse subsidy } \\
(50 \% \text { higher than } \\
\text { index } 1,1)\end{array}$} & \multicolumn{2}{|c|}{\begin{tabular}{|c|} 
Necessary \\
subsidy \\
(compensation \\
of $80 \%$ to index \\
0,9 ) \\
\end{tabular}} & \multirow{2}{*}{$\begin{array}{c}\text { The } \\
\text { number of } \\
\text { budgets } \\
\text { that do not } \\
\text { receive } \\
\text { base or } \\
\text { reverse } \\
\text { subsidies }\end{array}$} & \multirow{2}{*}{$\begin{array}{l}\text { The number } \\
\text { of funds } \\
\text { from the } \\
\text { state budget } \\
\text { used for } \\
\text { equalisation, } \\
\text { million UAH }\end{array}$} \\
\hline & & & & & $\begin{array}{c}\text { The total } \\
\text { amount, } \\
\text { mln. } \\
\text { UAH }\end{array}$ & $\begin{array}{c}\text { numbe } \\
r \text { of } \\
\text { budget } \\
s\end{array}$ & $\begin{array}{c}\text { total } \\
\text { amount, } \\
\text { mln. } \\
\text { UAH }\end{array}$ & $\begin{array}{c}\text { numbe } \\
r \text { of } \\
\text { budget } \\
s\end{array}$ & & \\
\hline & $\mathrm{A}$ & 1 & 2 & 3 & 4 & 5 & 6 & 7 & 8 & $9=6-4$ \\
\hline 1 & \begin{tabular}{|c|} 
The \\
effective \\
system of \\
horizontal \\
equalisation \\
\end{tabular} & 36814,9 & 95548,5 & 2595,4 & 7395,6 & 232 & 11239,4 & 1018 & 178 & 3843,8 \\
\hline 2 & $\begin{array}{c}\text { System of } \\
\text { horizontal } \\
\text { equalisation } \\
\text { taking into } \\
\text { account } \\
\text { national } \\
\text { payments * }\end{array}$ & 36814,9 & 112027,0 & 3043,0 & 9364,3 & 283 & 12675,2 & 973 & 172 & 3311,0 \\
\hline 3 & $\begin{array}{c}\text { System of } \\
\text { equalisation } \\
\text { taking into } \\
\text { account } \\
\text { personal } \\
\text { income } \\
\text { taxes in } \\
\text { Kyiv }\end{array}$ & 39940,6 & 114150,4 & 2858,0 & 9777,1 & 177 & 14774,2 & 1117 & 135 & 4997,1 \\
\hline 4 & $\begin{array}{c}\text { System of } \\
\text { equalisation } \\
\text { taking into } \\
\text { account } \\
\text { national } \\
\text { payments* } \\
\text { in Kyiv }\end{array}$ & 39940,6 & $\begin{array}{c}136 \\
887,4\end{array}$ & 3427,3 & 12773,0 & 218 & 17747,1 & 1081 & 130 & 4974,1 \\
\hline
\end{tabular}

* Revenues do not include local taxes, charges and fees for administrative services

Source: developed by the authors (State budget of Ukraine in 2017-2020). 

Decentralization Reform

An alternative variant of calculating the amount of necessary and reverse subsidies, which is innovative relative to the existing system, involves the inclusion of the city of Kyiv into the system of horizontal equalisation. Considering the special status of the capital, the city of Kyiv is not included in the system of horizontal equalisation of local budgets. Based on the conducted research we can see (Table 3 ) that the inclusion of the city of Kyiv in the horizontal equalisation system (considering only the personal income tax or including the personal income tax and other national payments) will increase: the number of local budgets that require a necessary subsidy; volumes of essential subsidies; state budget funds that will need to be raised to fund essential subsidies. It is because the share of revenues of the city of Kyiv in the structure of local budgets of Ukraine is quite high (16,3\% of the total income taxes of individuals and $18,2 \%$ of the amount of national taxes), which consequently leads to the formation of a higher average per capita income, which is a criterion for horizontal equalisation. Therefore, one should consider the advisability of including the budget of the city of Kyiv into the system of horizontal equalisation of Ukraine. Further research should be conducted in this area.

Another aspect of the study concerns the effectiveness of the system of horizontal equalisation in terms of reducing financial imbalances between local budgets. The study was based on a comparative analysis of the effectiveness of the current horizontal equalisation system (based only on personal income tax) and subject to consideration of all national payments (including personal income tax) in terms of the impact of base and reverse subsidies on the reduction of economic disproportions between local budgets. For this purpose, calculations were made using the function of standard deviation. The standard (mean square) deviation is the degree of deviation of all values from their mean indicators. The standard deviation shows how much individual values deviate from their mean values (Gusarov VM, 2003), that is, it gives an understanding of the range of changes in values relative to their mean values (the more significant the standard deviation, the more extensive the range of changes in values).

For our calculations, we use Microsoft Excel, in which the formula calculates the standard deviation:

$$
\sigma=\sqrt{\frac{\sum(\mathrm{x}-\overline{\mathrm{x}})^{2}}{(\mathrm{n}-1)}}
$$

where $(x-\bar{x})^{2}-$ the sum of squares of all deviations of individual values from their mean values; $\mathrm{n}$ - the number of observation results.

The basis for calculations was the data on the implementation of local budgets of Ukraine in 2018, which make it possible (considering the actual reporting data) to analyse the effectiveness of the financial equalisation system. According to the financial and statistical reports, the average indicator of actual per capita income tax in Ukraine was $2135,05 \mathrm{UAH}$. At the same time, the maximum value of the indicator was 19693,25 UAH per 1 person, the minimum one - 392,68 UAH per 1 person, that is, the difference between the extreme indicators was 50,2 times (Table 4). Taking into account the base and reverse subsidies, the average adjusted personal income tax rate in Ukraine was 2365,97 UAH per 1 person, the maximum value - 14731,57 UAH per 1 person, the minimum value -975,0 UAH per 1 person, that is the difference between extreme indicators was 15,1 times (table 4). Therefore, it can be concluded that, although financial equalisation does not eliminate the existing disparities between local budgets, it significantly reduces them. At the same time, we believe that financial equalisation of local budgets only using the personal income tax without taking into account other sources of income, is not entirely correct, because significant amounts of revenues are ignored, which in some cases significantly affects the level of financial capacity of the respective budgets.

For this reason, the actual revenues from state payments (excluding local taxes, charges and fees for administrative services), the amounts of base subsidies actually received by local budgets and the 

Decentralization Reform

amounts of reverse subsidies transferred to the state budget, were used for the analysis. Under these conditions, the deviation between the maximum and minimum indicators of actual revenues differed by 51 times, and with the base and reverse subsidies - by 15,9 times (Table 4). That is, in two variants (using the personal income tax and national payments) the indicators that characterise almost identical parameters characterise the level of differentiation of revenues between local budgets before and after their equalisation. It is because in the structure of revenues of local budgets (excluding transfers) the personal income tax is 59\% (Richnyi zvit pro vykonannia Derzhavnoho biudzhetu Ukrainy za 2018), that is, the overwhelming amount of revenues is generated through this tax.

The calculated value of standard deviation for personal income tax (per capita) is 1532,86, and considering equalisation, it is 1073,27 (Table 4). That is, taking into account the actual amounts of primary and reverse subsidies, the standard deviation (according to the criterion of personal income tax) decreased by $42,8 \%(1532,86 / 1073,27)$. The standard deviation calculated for the national per capita payments is 1828,01 , and considering the actual amounts of essential and reverse subsidies, its value is 1405,18 (Table 4). Given the actual amounts of the base and reverse subsidies, the standard deviation (according to the criterion of nationwide payments) decreased by $30,1 \%(1828,01 / 1405,18)$. The obtained results show that base and reverse subsidies have a more significant impact on the reduction of financial disparities between local budgets if their volumes adjust the fiscal capacity of local budgets taking into account only the personal income tax.

Table 4. Indicators of efficiency of the system of horizontal equalisation

\begin{tabular}{|c|c|c|c|c|c|}
\hline \multirow{2}{*}{$\begin{array}{c}\text { Serial } \\
\text { numbe } \\
\mathbf{r}\end{array}$} & Indicators & $\begin{array}{c}\text { Personal Income Tax (horizontal } \\
\text { equalisation system) }\end{array}$ & \multicolumn{2}{|c|}{ National payments * (estimation) } \\
\cline { 3 - 6 } & $\begin{array}{c}\text { actual per } \\
\text { capita } \\
\text { revenues } \\
\text { (UAH/1 person) }\end{array}$ & $\begin{array}{c}\text { actual revenues } \\
\text { taking into } \\
\text { account basic and } \\
\text { reverse per capita } \\
\text { subsidies } \\
\text { (UAH/1 person) }\end{array}$ & $\begin{array}{c}\text { actual per } \\
\text { capita } \\
\text { revenues } \\
\text { (UAH/1 } \\
\text { person) }\end{array}$ & $\begin{array}{c}\text { actual revenues } \\
\text { taking into account } \\
\text { basic and reverse } \\
\text { per capita subsidies } \\
\text { (UAH/1 person) }\end{array}$ \\
\hline 1 & Minimum value & 392,68 & 975,0 & 433,73 & 1324,85 \\
\hline 2 & Maximum value & 19693,25 & 14731,57 & 22125,80 & 21126,03 \\
\hline 3 & Median value & 1823,85 & 2115,57 & 2105,96 & 2402,47 \\
\hline 4 & Average value & 2135,05 & 2365,97 & 2520,18 & 2751,09 \\
\hline 5 & $\begin{array}{c}\text { The deviation between } \\
\text { maximum and minimum } \\
\text { values, times }\end{array}$ & 50,2 & 15,1 & 51,0 & 15,9 \\
\hline 6 & Standard deviation & 1532,86 & 1073,27 & 1828,01 & 1405,18 \\
\hline
\end{tabular}

${ }^{*}$ Revenues do not include local taxes, charges and fees for administrative services

On the other hand, the actual amounts of the base and reverse subsidies have a lesser impact on the equalisation of the fiscal capacity of local budgets if all national payments are taken into account. This fact is natural since the criterion for horizontal equalisation of taxability of local budgets is the personal income tax. Therefore, the current horizontal equalisation mechanism does not effectively eliminate financial imbalances between local budgets if we take into account all national revenues, not just the personal income tax. The equalisation of local budgets' taxability with only one type of revenues (personal income tax) cannot ensure the achievement of the main goal - the maximum possible equalisation of financial imbalances of local budgets. 

Decentralization Reform

Conclusions. Based on the analysis of the effectiveness of the financial equalisation system in Ukraine, we can make the following conclusions and propose new approaches to the management of the financial equalisation system:

The current system of horizontal equalisation is not self-balanced. The amounts of essential subsidies far exceed reverse subsidies, which leads to the necessity of attracting state budget funds to equalise the tax capacity of local budgets. In order to minimise inter-territorial disparities in Ukraine, it is necessary to broaden the financial base for financial equalisation, namely, to determine the tax capacity index is taking into account the personal income tax and other national payments to local budgets. The inclusion of Kyiv into the equalisation system will lead to:

- the increase in the amount of base subsidies and the number of budgets receiving base subsidies;

- the reduction in the number of budgets that transfer reverse subsidies to the state budget;

- the significant share of the total amount of reverse subsidies will be transferred by the city of Kyiv (from $44,9 \%$ to $51,2 \%$ );

- there will be an increase in the volumes of funds (compared to the current conditions), which will need to be transferred to the equalisation system from the state budget;

- the increase in the volumes of subsidy resources received by local budgets. That is, the amounts of local budget funds will increase and, at the same time, the indicator of dependence on transfers from the state budget will increase.

It is necessary to consider ways to increase the amounts of financial resources accumulated in the equalisation system. Along with the reverse subsidies, a financial equalisation fund should be formed in the state budget for its distribution between local budgets. The estimated volume of such fund should be at least $20-25 \%$ of the amount of local budgets' revenues. Today, this figure ranges from 11 to $12 \%$. Given the increase in resources aimed at balancing inter-territorial disparities, it will be possible to achieve a smaller standard deviation and, accordingly, to increase the financial capacity of local budgets with low financial and economic potential. In addition to improving the national system of financial and budgetary equalisation, it is advisable to consider the possibility of implementing specific equalisation mechanisms at the local level - the regional level. The existence of adequate tools for equalising financial imbalances between local governments at the level of regions would make it possible to take into account specific regional features (which are objectively impossible to consider at the national level) and thus increase the efficiency of the equalisation system.

In order to improve the system of financial equalisation and to expand the variant analytical series, it is advisable to research terms of individual levels of the budgetary system. For this purpose, it is necessary to carry out a separate calculation of primary and reverse subsidies for the budgets of cities of regional significance and amalgamated communities. The idea is to carry out a separate financial equalisation for each category of local budgets. As noted above, today the equalisation is carried out in the cities of regional significance and amalgamated communities using a single indicator of the taxability index. In making separate calculations the value of the taxability index will be determined separately for the budgets of cities of regional significance and amalgamated communities. The rationale behind this innovative approach is that the economic and financial potential of cities of regional significance is higher than that of amalgamated communities. The powers of authorities in the socio-cultural sphere and the sphere of life support of residents are more extensive in the cities of regional significance. Such analysis will provide additional information on the effectiveness of the system of financial equalisation of local budgets.

Author Contributions: conceptualisation, Y. P. and V. V.; methodology, Y. P. and V. V.; validation, V. G., W. D. and U. K.; formal analysis, W. D.; investigation, V. V.; resources, V. G.; data curation, Y. P and V. V.; writing-original draft preparation, Y. P., V. V.; writing-review and editing, U. K., V. G. and W. D.; visualisation, V. V. and U. K.; supervision, Y. P.; project administration, Y. P.; performed the analysis and visualisation of results, Y. P and V. V. 
Y. Petrushenko, V. Ventsel, V. Garbuz, U. Kolomiiets, W. Duranowski. Innovations in Management of Fiscal Equalisation: Decentralization Reform

Funding. The survey was supported by the Ministry of Education and Science of Ukraine and performed the results of the project «Development of scientific and methodological foundations and practical tools of the financial policy of sustainable development of the community» (registration number 0117U003935).

\section{References}

Albouy, D. (2012). Evaluating the efficiency and equity of federal fiscal equalisation. Journal of Public Economics, 96(9-10), 824-839. [Google Scholar] [CrossRef]

Anetsberger, G., \& Arnold, V. (2019). Horizontal versus vertical fiscal equalisation: the assignment problem. International Tax and Public Finance, 26(2), 357-380. [CrossRef] [CrossRef]

Annual Report on Implementation of the State Budget of Ukraine for 2018. Retrieved from https://www.treasury.gov.ua/ua/filestorage/richnij-zvit-pro-vikonannya-derzhavnogo-byudzhetu-ukrayini-za-2018-rik

Becker, J., \& Kriebel, M. (2017). Fiscal equalisation schemes under competition. International Tax Public Finance 24(5), 800816. [Google Scholar] [CrossRef]

Bilan, Y., Brychko, M. M., Buriak, A. V., \& Vasylieva, T. A. (2019). Financial, business and trust cycles: the issues of synchronisation. [Google Scholar]

Budget Code of Ukraine dated 08.07.2010 № 2456. Retrieved from https://zakon.rada.gov.ua/laws/show/2456-17/paran77\#n77

Chygryn, O., Petrushenko, Y., Vysochyna, A., \& Vorontsova, A. (2018). Assessment of Fiscal Decentralisation Influence on Social and Economic Development. Montenegrin Journal of Economics, 14(4), 69-84. [Google Scholar] [CrossRef]

Di Liddo, G., Longobardi, E., \& Porcelli, F. (2016). Measuring horizontal fiscal imbalance: the case of Italian municipalities. Local Government Studies, 42(3), 385-419. [Google Scholar] [CrossRef]

Gusarov, V.M. (2003). Statistics: Textbook. University manual]. Moskva: JUNITI-DANA.

Kanduła, S. (2017). The Efficiency of Fiscal Equalisation. The Case Study of Municipalities in Poland. Lex localis-Journal of Local Self-Government, 15(4). [Google Scholar] [CrossRef]

Kozarezenko, L., Petrushenko, Y., \& Tulai, O. (2018). Innovation in Public Finance Management of Sustainable Human Development. Marketing and Management of Innovations, 4, 191-202. [Google Scholar] [CrossRef]

Leonov, S. V., Vasylieva, T. A., \& Tsyganyuk, D. L. (2012). Formalisation of functional limitations in functioning of co-investment funds basing on comparative analysis of financial markets within FM CEEC. Actual Problems of Economics, (134), 75-85.

$\mathrm{Li}$, Y. (2018). Asymmetric decentralisation, intergovernmental transfers, and expenditure policies of local governments. Frontiers of Economics in China, 13(2), 223-249. [Google Scholar] [CrossRef]

Musa A. Subeh, V. Boychenko. (2018). Causes, Features and Consequences of Financial Crises: a retrospective cross-country analysis. Financial Markets, Institutions and Risks, 22), 111-122. [Google Scholar] [CrossRef]

On Amendments to the Budget Code of Ukraine on Reform of Intergovernmental Relations: Law of Ukraine of 28.12.2014 No. 79-VIII. Retrieved from https://zakon.rada.gov.ua/laws/show/2456-17/paran77\#n77

On the State Budget of Ukraine for 2017: Law of Ukraine of 21.12.2016 No. 1801-VIII. Retrieved from https://zakon.rada.gov.ua/laws/show/1801-19

On the State Budget of Ukraine for 2018: Law of Ukraine dated 07.12.2017 No. 2246-VIII. Retrieved from https://zakon.rada.gov.ua/laws/show/2246-19

On the State Budget of Ukraine for 2019: Law of Ukraine of 23.11.2018 No. 2629-VIII. Retrieved from https://zakon.rada.gov.ua/laws/show/2629-19

On the State Budget of Ukraine for 2020: Law of Ukraine of 14.11.2019 No. 294-IX. Retrieved from https://zakon.rada.gov.ua/laws/show/294-20

Palienko M., Lyulyov O., Denysenko P. (2017). Fiscal Decentralisation as a Factor of Macroeconomic Stability of the Country. Financial Markets, Institutions and Risks, 14), 74-86. [CrossRef]

Tiutiunyk, I.V. (2018). Determination of Priority Financial Instruments of Regional Sustainable Development. International Journal of Ecology \& Development,33(3), 1-18.

Vasylieva, T. A., Harust, Y. V., Vynnychenko, N. V., \& Vysochyna, A. V. (2018). Optimisation of the financial decentralisation level as an instrument for the country's innovative economic development regulation. Marketing and Management of Innovations, 4, 382-391. [Google Scholar]

Yasemin Irepoglu Carreras (2016) Fiscal decentralisation and inequality: the case of Spain. Regional Studies, Regional Science, 3(1), 295-302. [CrossRef]

Yilmaz, S., \& Zahir, F. (Eds.). (2020). Intergovernmental Transfers in Federations. Edward Elgar Publishing. [Google Scholar] [CrossRef] 
Y. Petrushenko, V. Ventsel, V. Garbuz, U. Kolomiiets, W. Duranowski. Innovations in Management of Fiscal Equalisation: Decentralization Reform

Юрій Петрушенко, Dr. Sc., професор, Сумський державний університет (Україна);

Віктор Венцель, Ph.D., Національна академія державного управління при Президентові України (Україна);

Вероніка Гарбуз, Ph.D., Бєлцьський державний університет імені Алеку Руссо (Молдова);

Ульяна Коломієць, Карлів університет, Інститут економіки Чеської академії наук (Чехія);

Войцех Дурановскі, Ph.D., Університет Ополє (Польща).

Інновації в управлінні фіскальним вирівнюванням: реформа децентралізації

Стаття присвячена обгрунтуванню доцільності запровадження інноваційних підходів до підвищення ефеективності системи фінансового вирівнювання та оперативного управління фінансовими дисбалансами територій в умовах реалізації реформи децентралізації. Проведене дослідження узагальнюе результати наукового аналізу дієвості системи горизонтального фінансового вирівнювання як інструменту зменшення міжтериторіальних економічних та соціальних диспропорцій. Предметом дослідження є процеси управління системою фінансового вирівнювання в Україні в період з 2015 року, оскільки саме в цей час розпочалася реформа децентралізації, основою якої є перерозподіл фінансових ресурсів. Наявність низки невирішених практичних, а відтак і теоретико-методологічних завдань в процесі реалізації політики фінансового вирівнювання в Україні в період 2015-2020 років обумовило актуальність дослідження. Методичним інструментарієм дослідження став порівняльний аналіз діючої в Україні системи горизонтального фінансового вирівнювання з точки зору ії ефрективності щодо забезпечення зменшення міктериторіальних фіскальних дисбалансів та оцінка ефективності запропонованих авторами інноваційних підходів до управління системою фінансового вирівнювання. Для верифікації отриманих результатів були використані статистичні та економетричні методи дослідження. Результати дослідження засвідчили, що існуючий підхід до фінансового вирівнювання диспропорцій у спроможності місцевих бюджетів України не ефективний та потребує вдосконалення. Розроблено нові управлінські підходи в системі фінансового менеджменту територій, що спрямовані на вдосконалення механізму горизонтального вирівнювання місцевих бюджетів, зокрема, на зменшення кількості місцевих бюджетів, що отримують з державного бюджету базову дотацію, та на підвищення ефективності системи горизонтального вирівнювання з точки зору зменшення фінансових диспропорцій між місцевими бюджетами. 3 огляду на ці цілі проведено аналіз включення столиці (м. Київ) до загальнодержавної системи фінансового вирівнювання. У дослідженні також обгрунтовано необхідність перманентного моніторингу дієвості фінансового вирівнювання. Для більш чіткого розуміння того, наскільки ефективно функціонуе система горизонтального вирівнювання фінансових доходів територій запропоновано здійснювати постійний (щорічний) аналіз показників стандартного відхилення та інших індикаторів, які характеризують ї̈ ефективність. Результати дослідження можуть бути корисними як для державних органів, що здійснюють планування та виконання державного бюджету, так і для реалізації локальної фінансової політики органами місцевого самоврядування

Ключові слова: управління, інновації, фінансове вирівнювання, бюджет, дисбаланс, асиметрія, децентралізація.

Manuscript received: 20.12.2019.

(C) The author(s) 2020. This article is published with open access at Sumy State University. 